\title{
Social capital, 'Ghent' \\ and workplace contexts \\ matter: Comparing union \\ membership in Europe
}

\author{
Bernhard Ebbinghaus, Claudia Göbel and \\ Sebastian Koos \\ Universität Mannheim, Germany
}

\begin{abstract}
Union density still varies considerably across Europe. This cross-national diversity has inspired multiple explanations ranging from institutional to workplace or socio-demographic factors. In this comparative multilevel analysis, we combine personal, workplace and macro-institutional explanations of union membership using the European Social Survey. By controlling for individual factors, we test the cross-national effect of meso- and macro-level variables, in particular workplace representation, establishment size, Ghent unemployment insurance and a society's social capital. We conclude that all these institutional and social contextual factors matter in explaining differences in union membership.
\end{abstract}

\section{Keywords}

membership, social capital, trade unions, unemployment insurance, union density workplace representation

\section{Introduction}

Membership mobilization is crucial for trade unions as voluntary organizations. Members provide financial resources, collective action in the case of strikes and electoral votes. Most importantly, they ensure trade unions' capacity to sign and implement collective agreements and influence government policy. Therefore, membership is of vital importance not only for unions themselves but also for the analysis of labour relations in society.

Multiple comparative studies have recorded a substantial decline in unionization in most European countries. Nevertheless, union density - union membership relative to all employees - still varies considerably across Europe; some unions are more able than

\section{Corresponding author:}

Bernhard Ebbinghaus, MZES, Universität Mannheim, D-68I3I Mannheim, Germany

Email: ebbinghaus@uni-mannheim.de 
others to mobilize the workforce (Ebbinghaus and Visser, 1999). Several partly competing, partly complementary explanations have been provided for these cross-national differences, encompassing individual, structural and institutional causes. These have been empirically tested using micro-level survey research, organizational case studies and comparative macro-level institutional analyses (Schnabel, 2003; Wallerstein and Western, 2000). The interplay of institutions, organizational and individual traits, however, has been largely neglected in empirical studies (for an exception, see Brady, 2007).

In this article, we perform a multilevel analysis of union membership, combining data from the first round (2002/03) of the European Social Survey (ESS) with macro-level data for 19 European countries. We explore how the individual decision to become or remain a union member is embedded in the workplace context as well as in the more or less conducive social and institutional environment of a country. In this study, we will focus on four aspects of the social and institutional context: the access of unions to the workplace, the firm size, the selective incentive of union-administered so-called 'Ghent' unemployment insurance and a civil society's social capital. Whereas previous comparative research has highlighted the particular importance of the first three factors (Schnabel, 2003; Wallerstein and Western, 2000), social capital has been mostly absent in union membership studies despite the recent prominence of social capital theory (Putnam, 2002).

First, we briefly introduce the theoretical background, discuss empirical findings and deduce our hypotheses. After explaining the multilevel analysis used, we present our findings. Ghent and social capital both increase the chance of being a union member. Furthermore, the effect of organizational variables like firm size and workplace union representation varies across systems. In the conclusion, we discuss our main findings.

\section{Explaining union membership}

\section{Theoretical approaches}

In order to explain union membership, we resort to several main theoretical paradigms, in particular economic theory, which has advanced an individual rational-choice model, and sociological perspectives such as social custom and social capital theories, which provide more norm-oriented explanations. Rational-choice explanations assume that individuals are utility-maximizers (Olson, 1965): they decide to become or remain union members if the expected benefits of membership exceed the known (opportunity) costs. On this assumption, union membership is understood as the result of employees' demand for union representation (and services) and trade unions' supply of these goods (Schnabel, 2003). Accordingly, an employee's decision is influenced by several factors: membership dues, individual income, the gains resulting from union bargained wages, non-pecuniary benefits from a unionized work environment (such as better working conditions) and services like social welfare benefits. ${ }^{1}$ The supply of union services depends on the costs of organizing and servicing new or existing members. These are expected to be smaller in larger firms (given decreasing recruitment costs for each additional union member) and are influenced by employers' attitudes toward unions as well as the political or legal opportunity structure within which unions act (Schnabel, 2003). 
In addition, trade unions as voluntary organizations face the free-rider problem (Olson, 1965). They produce collective goods in the form of agreements on wages, working time and conditions from which non-unionized workers cannot easily be excluded. But why do people then decide to join unions? Olson suggests two mechanisms: negative and positive incentives. Negative incentives or sanctions can work either informally, when an individual is subject to social pressures applied by peer groups, or formally, when membership is required before or after starting work. Such 'closed shop' contracts are based on collective agreements which oblige the employer to hire only union members; but this mechanism is now outlawed in most European countries.

Positive incentives are selective benefits from union-provided 'club' goods (strike pay, legal advice and protection, social insurance, information and training). Loyalty and recruitment problems only arise when union services are offered elsewhere at lower costs. Hechter (2004) considers union membership decline to be decisively caused by the expansion of welfare states in advanced societies, an argument developed earlier by van de Vall (1970). Today, welfare states provide insurances against risks of unemployment, sickness and retirement that unions once offered. This has 'led to the erosion of key incentives for union membership' (Hechter, 2004: 426-427). Where social insurances are still run by unions, which is the case for the Ghent unemployment insurance scheme in Nordic countries (except Norway), high rates of union membership can be observed (Rothstein, 1992).

From a sociological perspective, union membership can be interpreted in terms of Weber's four general categories of social action (1922). First, the decision to join a union can be based on instrumental-rational motives: people organize in order to assert their personal interests, obtain reputation and get access to desired goods. They might collude to exclude others from access to their resources (social closure). Second, following Weber's concept of value rationality (Wertrationalität), the principle of solidarity, the identityforming function of union membership as well as ideological (political, ethical or religious) convictions can play a significant role (Boudon, 1979). Third, people may feel emotionally associated with the community of unionized colleagues or friends and become members for affectual reasons without calculating costs and benefits. Fourth, union membership can arise from traditional motives: one's parents have been members or there is a tradition of unionization at the workplace. In this case, union membership is enforced by social customs (Akerlof, 1982; Visser, 2002) and expectations (Hechter, 1987).

'Social custom' theory postulates that an employee will be more willing to unionize if others do the same, thus assuming a critical mass of members (at workplace, industry or society level) as a prerequisite of favourable social expectations (Booth and Chatterji, 1993). As part of an interactionist perspective, this approach emphasizes the importance of an individual's embeddedness in union-friendly social networks (family, circle of friends, neighbourhood and colleagues at workplace) in which positive beliefs about trade unions are socialized.

The concept of social capital points to the benefits that an individual aims to achieve from involvement in social networks (Bourdieu, 1983). Social capital is important at both the individual and the country level (Putnam, 2000, 2002). Two components can be distinguished: first, a normative dimension as generalized trust; second, a structural dimension as involvement in civic networks and associations. Both dimensions advance 
cooperative behaviour, sense of community and solidarity, which are essential for the functioning of democratic institutions. For these reasons, countries with high social capital should constitute an environment conducive for collective organization, while individuals with high social capital should be more likely to be union members.

In addition, a society's institutional framework can be a fundamental determinant of unionization. The 'varieties of capitalism' approach (Hall and Soskice, 2001) and theories of corporatism (e.g. Crouch, 1993), most prominently, entail assumptions on the impact of tripartite wage setting and policy-making between trade unions, employers and government. In corporatist systems, the opportunity structure will favour union membership, since unions are strongly recognized and less opposed by employers (Ebbinghaus and Visser, 1999). According to power resources theory (Korpi, 1983), a union-friendly environment can also derive from left-wing governments that promote pro-union industrial relations and advance welfare state policies, expanding decommodified social rights and public social services.

Among the numerous institutional variables explaining union membership, crossnational research has highlighted the positive effect of Ghent systems. Union-run unemployment insurance provides a selective incentive for employees to join a trade union and leads to positive attribution of a public-good function to unions. This may explain why employees in such countries tend to stay unionized even in times of high unemployment (Ebbinghaus and Visser, 1999; Olson, 1965; Rothstein, 1992; Western, 1997). Thus, we can conclude that an individual's decision to unionize can be based on a variety of motives strongly influenced by the working environment and living conditions. This social and institutional context is in turn shaped by trade unions as well as by the wider economic, political and societal context.

\section{Personal characteristics (individual level)}

Personal characteristics, for instance age, sex and education, all affect union membership in specific ways. Empirical studies show that the probability of joining a union varies over the life course: it is greatest when an apprentice (or trainee) is offered a permanent position, particularly in workplaces with union representation. Later in working life, recruitment problems increasingly emerge and the propensity to leave the union grows at the end of the working life with (early) retirement (Ebbinghaus, 2006). In general, the relation between age and unionization is expected to be concave: membership tends to be low among younger workers, increases with age and falls when employees exit from work. Ebbinghaus et al. (2008) document this pattern for nearly all European countries (also using ESS data from 2002/03). Longitudinal data are however needed to distinguish age from cohort effects.

Explanations for this pattern vary. The age gap may be caused by differences between generations (birth cohorts) in attitudes to unions or identification with them (Fitzenberger and Beck, 2003; Schnabel and Wagner, 2005). Furthermore, in countries with high youth unemployment or atypical work as well as low levels of training, young people will be less willing to commit themselves to long-term membership. In contrast, it is assumed that older employees have a closer relationship to their workplace because of their higher job tenure and firm-specific human capital than younger workers entering jobs. They also 
tend to be more interested in staying in their current job or with their current employer. Finally, unions may have less interest in recruiting current young cohorts as they are relatively small, while younger workers may be less interested in joining organizations that they perceive to represent largely the interests of older workers (Ebbinghaus, 2006).

Employees with low (less than secondary) or high (tertiary) education are often reported to be less unionized than those with medium-level (secondary) education. Although lower skilled blue-collar workers belong to the traditional clientele of general or industrial unions, they are represented to a lower degree than their more skilled colleagues. Since their number has decreased in Europe, trade unions might not make substantial efforts to organize the unskilled. But unions also fail to organize the growing number of employees in lower service jobs, particularly those with frequent job changes (Ebbinghaus, 2006; Schnabel and Wagner, 2005). In contrast, high-skilled employees 'usually have greater individual bargaining power (and thus a lesser need for collective voice), and sometimes they identify more with management than with the labour movement' (Schnabel, 2003: 30). With the exception of the public sector and some well organized professions (particularly in Nordic countries), better educated employees, particularly those with tertiary (university) education tend to be less likely to join trade unions.

Aggregate membership statistics show a lower unionization of women (Ebbinghaus and Visser, 1999). This gender gap is commonly explained by women's weaker attachment to the labour market 'due to family reasons and their lower average income compared to males' (Fitzenberger and Beck, 2003: 6), particularly in Continental and Southern Europe. Moreover, women disproportionately work in part-time jobs that are less unionized; but since the early 1980s 'the gender gap in unionization is narrowing' (Visser, 2003: 397), even disappearing or reversing in nearly half of 20 European countries (Ebbinghaus et al., 2008). The following multivariate analysis will shed some light on confounding factors such as atypical work that might explain gender differences.

Political and social attitudes are also seen as factors influencing collectivist orientation and thus union membership. Seen from a Weberian value-rationality perspective, ideological convictions may influence an individual's decision to unionize. A communist may be a union member out of conviction to change society, not out of a personal interest to gain higher wages. Empirical studies ascertain that union members characterize themselves as left-oriented (Schnabel, 2003). In addition, some scholars have found empirical evidence for the 'dissatisfaction' thesis: employees join a union if they are not satisfied with the way things are handled at the workplace (Guest and Dewe, 1988; Schnabel and Wagner, 2005). Other attitudes positively correlated with union membership are trust in trade unions (Windolf and Haas, 1989) and the subjective perception of their capacity to produce the desired goods (Guest and Dewe, 1988).

Empirical studies on social capital show cross-national variations along a North/West versus South/East gradient in Europe, indicating that Nordic Protestant societies tend to be endowed with more social capital than Southern Catholic societies or Eastern European transition economies (Putnam, 2002). Our previous analysis shows that in all European countries, union members are more often organized in non-union associations (Ebbinghaus et al., 2008). Other studies have stressed the impact of 'significant others' such as partners, friends and relatives (Goerke and Pannenberg, 1998; Ingham, 1995; Windolf and Haas, 1989), indicating the importance of social networks. These findings 
seem to confirm social custom and social capital theory, indicating that union members tend to be more community-oriented and better embedded in social networks. Contacts with unionized members further increase the probability of union membership.

Occupational and class positions have been seen as important for the collectivist orientation and mobilization potential of employees. Unions traditionally seek to organize blue-collar workers, facilitated by the fact that they have relatively homogeneous preferences and working conditions (Hirsch and Addison, 1986). Unionization is prevalent in the public service where trade unions are usually recognized by the state as employer and collective bargaining is common (Ebbinghaus, 2006; Traxler, 1999). In contrast, unions face substantial difficulties with access to small-scale private service firms (Ebbinghaus, 2006), thus supporting a cost-benefit explanation of union membership. Unfortunately, the ESS 2002/03 does not provide a public/private-sector coding, and we therefore cannot control for this important difference.

Recruitment problems also occur with regard to the growing number of the atypically employed. With the exception of some Southern and Eastern European countries, part-time employees are less frequently union members than full-time workers (Ebbinghaus et al., 2008). This gap between atypical and standard employment becomes even clearer in the case of fixed-term contracts. Probably the atypically employed have weaker ties to their current workplace as a result of their shorter working time or job tenure. Also from the unions' perspective, these employees are much more difficult to recruit, and because of restricted resources but also an intra-democratic representative logic, unions concentrate on organizing the already well-unionized groups. This in turn makes unions less attractive to the underrepresented groups (Ebbinghaus, 2006); even if the latter do join a union, they are more likely to abandon membership again because of job and income insecurity.

\section{Firm and workplace contextual factors (meso-level)}

Firm and workplace characteristics play a crucial role in unionization (Ebbinghaus and Visser, 1999). Countries differ widely in the extent to which unions are represented at the workplace. Having an organizational agent at the workplace level of the firm, unions are capable of directly influencing their membership base and provide services to them. With such access, unions can visibly and effectively represent the interests of the workforce and better recruit new members (Hancké, 1993; Kjellberg, 1983). In addition, a rising degree of unionization at the workplace may change social values and expectations in favour of union membership, leading to a quasi-closed shop.

The propensity to have a union at workplace is likely to increase with firm size because 'in large, homogeneous organizations with a bureaucratic nature and a low turnover' (Schnabel, 2003: 30) rate, the costs of organizing and servicing members tend to be lower (so-called economies-of-scale effect). Here, 'workers are likely to be treated impersonally and feel a greater need for representation and protection' (Schnabel, 2003: 30). In addition, workplace access and firm size are correlated: the larger the firm (or workplace), the more likely that statutory works councils and/or union shop stewards are present (Rogers and Streeck, 1995). That might explain why union density is higher in the public sector as well as among manual workers in manufacturing (Clegg, 1976). 


\section{Institutional context factors (macro-level)}

Besides these socio-demographic and structural explanations, which focus on personal characteristics of union members and on workplace contexts, the wider institutional, political, and socio-economic context must be taken into account when explaining crossnational differences in union membership (Ebbinghaus and Visser, 1999; Schnabel, 2003; Western, 1997). Most importantly, cross-national studies consistently find high union density rates in the Nordic countries (Sweden, Denmark, Finland) and Belgium, attributing these to the positive effect of their Ghent unemployment systems. In the Nordic countries, voluntary unemployment insurance funds are set up by the unions and subsidized by the state. In Belgium, mandatory unemployment insurance claims are partly administered by union officials. Although union membership is not mandatory for those insured, union-run insurance functions as a 'selective incentive' (Olson, 1965) for employees to join unions or remain a member when losing their jobs (Ebbinghaus and Visser, 1999; Western, 1997). Other selective incentives, like strike pay, legal advice and protection, may also be important motives for becoming a trade union member, but comparative data are lacking and therefore will not be explored in our multilevel analysis.

In addition, neo-corporatist scholars have emphasized the role of wage coordination and corporatist policy-making between unions, employers and the government (Western, 1997), the influence of left or right cabinets (Brady, 2007; Korpi, 1983; Wallerstein, 1989; Western, 1997) and social welfare expenditure (Brady, 2007; Hechter, 2004). All these factors are seen as strengthening union bargaining capacity. Moreover, economic context factors, like inflation, unemployment, economic growth, globalization and deindustrialization, are assumed to have an impact on union membership (Bain and Elsheikh, 1976; more recently, Brady, 2007). We analysed these political and economic factors (results not presented here) but, like Brady (2007), could not find significant effects. We therefore will not consider these economic factors in the following cross-sectional analyses but focus on the institutional incentive of Ghent unemployment insurance.

\section{Method and data sources}

In order to test the above hypotheses, we estimate multilevel models of an employee's membership in a trade union across 19 European countries. The logistic multilevel models seek to predict the odds that a dependent gainfully employed person is a union member based on a set of individual, workplace related and country-level predictors.

The individual-level data are drawn from the first wave of the ESS, which is a crossnational representative survey of randomly selected individuals residing in 21 European countries (see http://www.europeansocialsurvey.org). Because of missing data - in Switzerland and the Czech Republic, questions on organizational membership were not asked in the survey - we had to limit our sample to 19 European countries (but separating West and East Germany). Our dependent variable, union membership, was coded by combining two questions on past and current union membership. ${ }^{2}$ This combination increases the validity of our measurement of membership. Unfortunately, one question on union membership and characteristics, which is also the basis of our 
operationalization of social capital, was not repeated in subsequent waves of the ESS. We therefore restrict our study to a cross-national and cross-sectional analysis of the first wave.

Apart from these data limitations, the ESS 2002/03 provides enough cross-national variation to allow for multilevel analysis, and contains sufficient demographic and occupational information to assemble a reasonable individual-level model. We limit our analysis to gainfully employed persons, thus excluding the unemployed, other inactive and the self-employed, leaving us with 13,039 respondents aged between 16 and 70 in 19 European countries.

Our dependent variable is union membership, while the individual-level independent variables are gender (male $=1$, female $=0$ ), age (in years), years of education, atypical employment (workers with a fixed-term contract or part-time position $(<35$ hours per week)), social class (EGP class schema), left-wing political views (self-positioning on political left-right scale: $0=$ right, $10=$ left), opinion on need for strong unions (no need for strong unions $=1$, need for strong unions $=5$ ), and social capital (number of memberships in associations other than trade unions, as three dummy variables for membership in 1,2 and 3 or more associations) (Ebbinghaus et al., 2008). Additionally for both age and education, squared terms are included to control for the expected curvilinear relationship of both factors. The meso-level variables encompass two characteristics of the respondent's work context: perceived union presence at the workplace (dummy variable coded 1 for union representation at workplace) and establishment size (group of four dummy variables).

On the macro-level, we include a dummy variable for a Ghent unemployment insurance system in the case of Belgium, Denmark, Finland and Sweden. A country's social capital is measured as the share of employees with at least one membership in an association other than a trade union (Ebbinghaus et al., 2008). As a national indicator of workplace representation we aggregated the share of employees that are aware of 'a trade union or similar organization' at their workplace. Furthermore, to test for the interaction effect of macro-institutions and meso-level working context, cross-level interactions between Ghent and union representation at workplace as well as Ghent and firm size (a five-point continuous variable) are computed.

Our analysis applies logistical random intercept regression models, using Stata 10 (Rabe-Hesketh and Skorndal, 2008). Such multilevel models are increasingly used in cross-national research to account for the hierarchical data structure of individuals nested within countries. It assumes that two randomly chosen individuals from the same country will be more similar than two individuals from different countries. Since 'standard statistical tests lean heavily on the assumption of independence of observations', this assumption is clearly violated using cross-sectional data of individuals and would lead to 'spuriously significant results' (Hox, 2002: 5). Random intercept models allow an unbiased estimation of standard errors and are superior to country-fixed-effects models. Furthermore, the multilevel design allows introducing contextual level variables (like institutional characteristics) that help explain the overall variance. Finally, multilevel models also allow for random slopes between groups, thus cross-level-interactions between macro- and micro-level can be adequately estimated. This accounts for the fact that context factors (e.g. Ghent) can alter the effect of individual level variables (e.g. workplace representation). Thus context factors could explain varying slopes of micro-level models across countries. 


\section{Cross-national variations in unionization}

Our results based on ESS data show significant variations in union membership across Europe (Figure 1, and for more descriptive data: Ebbinghaus et al., 2008). In 2002/03, the Southern European countries Spain, Greece and Portugal feature the lowest union density rates $(11 \%)$, while Denmark is by far the most-unionized country in Europe (84\%), followed by Sweden (77\%), Finland (67\%), Norway (58\%) and then Belgium (44\%). Of the five top countries, all but Norway profit from union-run (or at least union-administered) Ghent unemployment insurances. With the exception of Slovenia, the Eastern European transition economies are among the lower organized union movements. Interestingly, Ireland with its more corporatist arrangements shows a higher level than neighbouring UK. Continental European countries with corporatist traditions rank only at a medium level, whereas Luxembourg, Austria and Netherlands have higher self-reported membership than Germany (East and West). A comparison with the 2002 net union density reported by the ICTWSS database ${ }^{3}$ shows a generally high validity of our density measurement. ${ }^{4}$

\section{Micro-level analysis of union membership}

First, we analyse the micro-models before turning to the macro-institutional results. In Table 1, we present odds ratios for six models for individual and meso-level contextual explanatory variables of union membership. Most effects are robust over all models predicted. Strikingly, gender loses its significant effect after controlling for atypical employment. This suggests that the often observed gender differences are the result of particular gendered employment pattern. Respondents who either have a non-permanent contract or

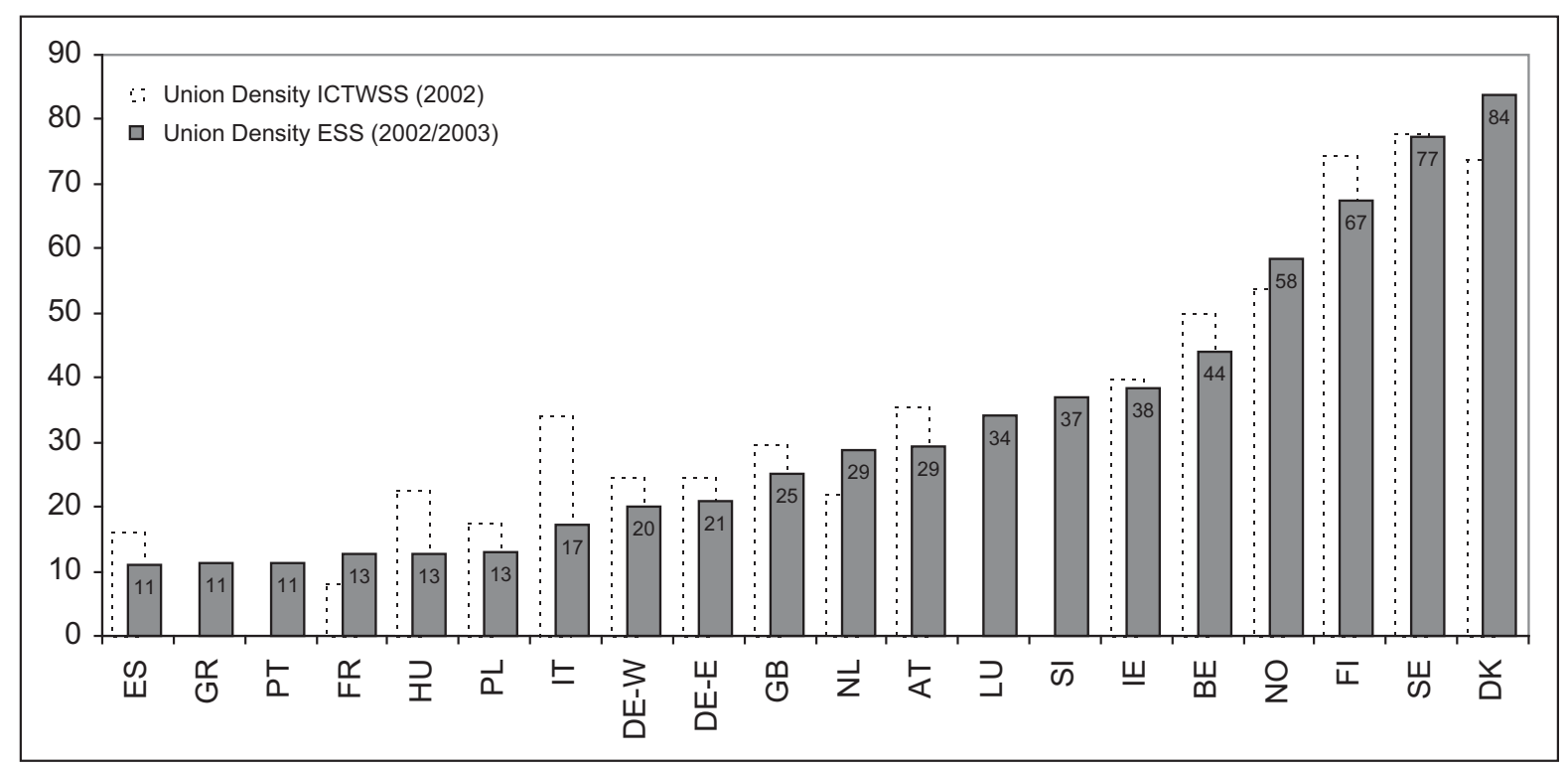

Figure I. Union density according to ESS and ICTWSS for 2002 (\%). Note: ICTWSS figures are missing for Greece, Portugal, Luxembourg and Slovenia. Source: Own calculations based on ESS 2002/03 and ICTWSS database data for 2002. 


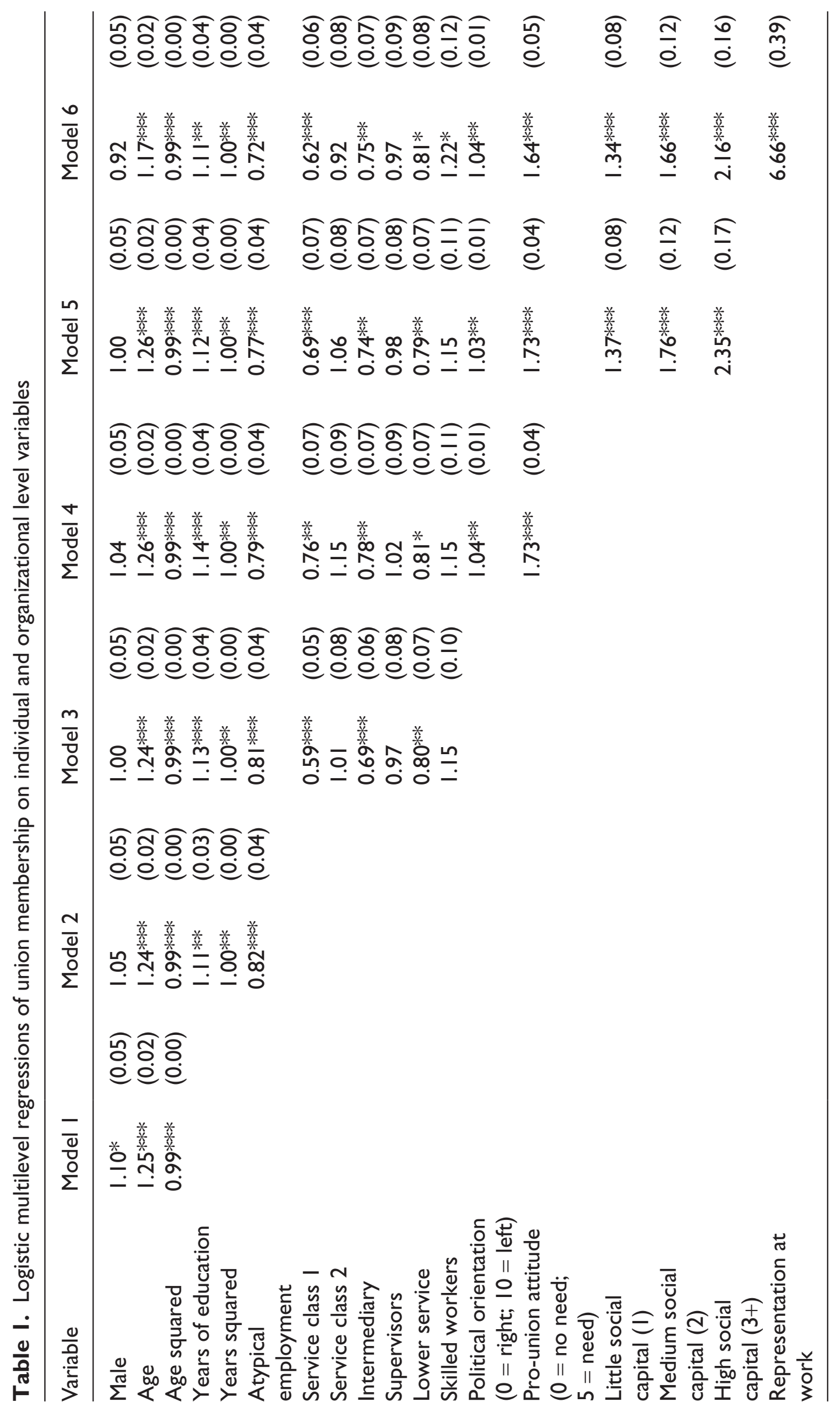




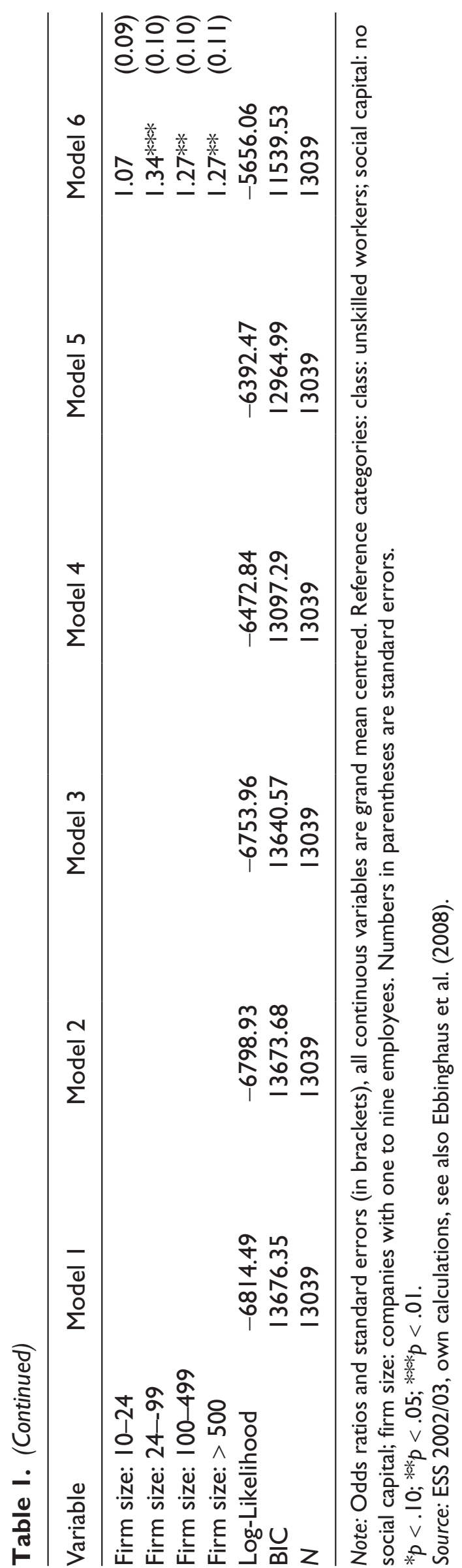


work part-time have on average a 4.5 percent smaller probability of being a union member than full-time employees with an unlimited contract, holding all other variables at their mean.

For both age and years of education, we find a curvilinear relationship with union membership. With increasing age until around 54, the likelihood of union membership increases, while it declines thereafter. However, we cannot rule out that our results are confounded with cohort effects, which cannot be distinguished from age effects in this cross-sectional design.

With increasing years of education, the probability of being a union member first increases and then decreases at about 15 years of full-time education (that is, with a university degree). We also substituted education years by education level, distinguishing between primary, secondary and tertiary education, but did not find a significant difference between tertiary and secondary education (results not presented). Socioeconomic class effects can be detected: routine non-manual workers and lower service workers (service class I) have a significant smaller probability of being in a union than unskilled workers, holding all other variables at their mean.

When included in the same model, political self-placement has a significant but moderate effect on union membership, whereas a positive assessment of the importance of unions strongly affects the likelihood of union membership. Finally, we do find a strong significant effect of social capital (outside unions): members of at least three non-union associations have on average a 16.1 percent higher likelihood of being a union member than people with no social capital, holding all other variables at their mean. The causality may go both ways: union members tend to be active beyond their union, but those that are well connected through multiple associations tend to become members of unions. Thus, it is not the case that unions necessarily compete with other societal organizations for limited resources of individuals (membership dues and time).

In addition to these personal traits, individuals are also embedded in organizational and institutional contexts. Before we turn to macro-level factors, we discuss organizational variables that are per se meso-level context indicators, but have been measured at respondent level. The presence of a trade union at the workplace (at least as perceived by the respondent) is a strong predictor of union membership, increasing the membership likelihood by 18.6 percent on average across all countries. In addition, the size of the establishment in which a respondent works has a distinct effect: respondents who work in a firm with 25 or more people have on average a 3.5 percent higher likelihood of being organized. While such an interpretation of individual and workplace-related factors is relatively parsimonious, it entails the problem of vague predictions for specific countries given the cross-national differences in institutional and social contexts.

\section{Macro-level analysis of union membership}

Turning to the macro-models, we present results for institutional and social contextual factors. Since the individual effects do not change substantially from the models presented thus far, we omit the individual level results from Table 2 that presents five macro-models. The first three consist of the Ghent effect and cross-level interaction effects of Ghent with firm size and workplace representation, both measured at the individual level. As predicted in the theoretical discussion, union-administered 


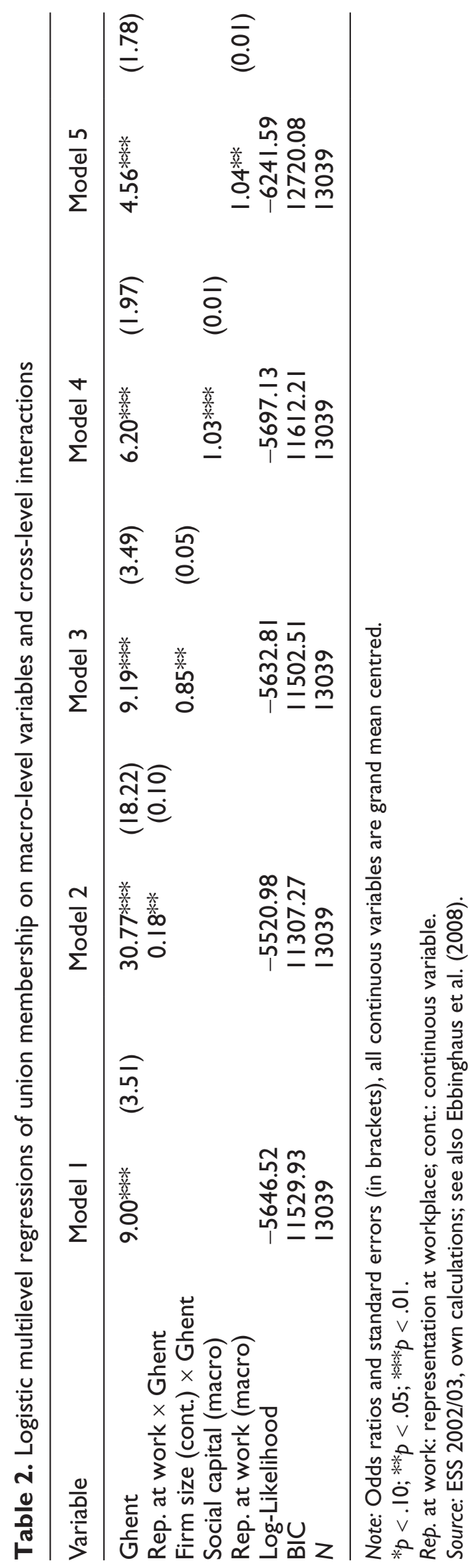


unemployment insurance is a strong predictor for union membership as it provides a strong selective incentive. The availability of a Ghent system on average increases the likelihood of being organized by 37.8 percent, holding all other variables at their mean (see Model 1). Additional models (not reported) testing Ghent against a large variety of institutional and socio-economic factors substantiate the strength of this effect. In all models computed, union responsibility for unemployment insurance shows a strong robust positive significant effect. To assess whether the Ghent dummy just captures some underlying effect of the Nordic countries, a separate model was estimated with data for Norway, Sweden, Denmark and Finland. Using the non-Ghent country Norway as the counterfactual case, the Ghent effect retained significant and positive (results not presented).

Ghent being such a powerful variable is assumed to influence the effects of individual and organizational-level variables by changing the underlying logic of organizing labour. In order to assess the influence of Ghent on the effects of the organizational variables workplace representation and firm size, ${ }^{5}$ we calculated cross-level interactions of Ghent at the macro level with workplace representation and firm size respectively at the respondent's level (see Figure 2).

The cross level interaction of the two dummy variables Ghent and workplace representation have a significant effect $(p<0.01)$ on union membership (see Model 2). Ghent systems alter the effect of workplace representation (Figure 2a): the effect of workplace representation is smaller in Ghent countries than in the other countries. Ghent unemployment insurance thus provides a selective incentive independent of workplace level, while workplace access is particularly important in countries where unions lack this advantage. We find a similar pattern for firm-size (Figure $2 b)$ : the cross-level interaction is again significant $(p<0.01)$ (Model 3). In Ghent countries, increasing firm size decreases slightly the effect of being a union member due to the Ghent incentive when controlling for everything else (since

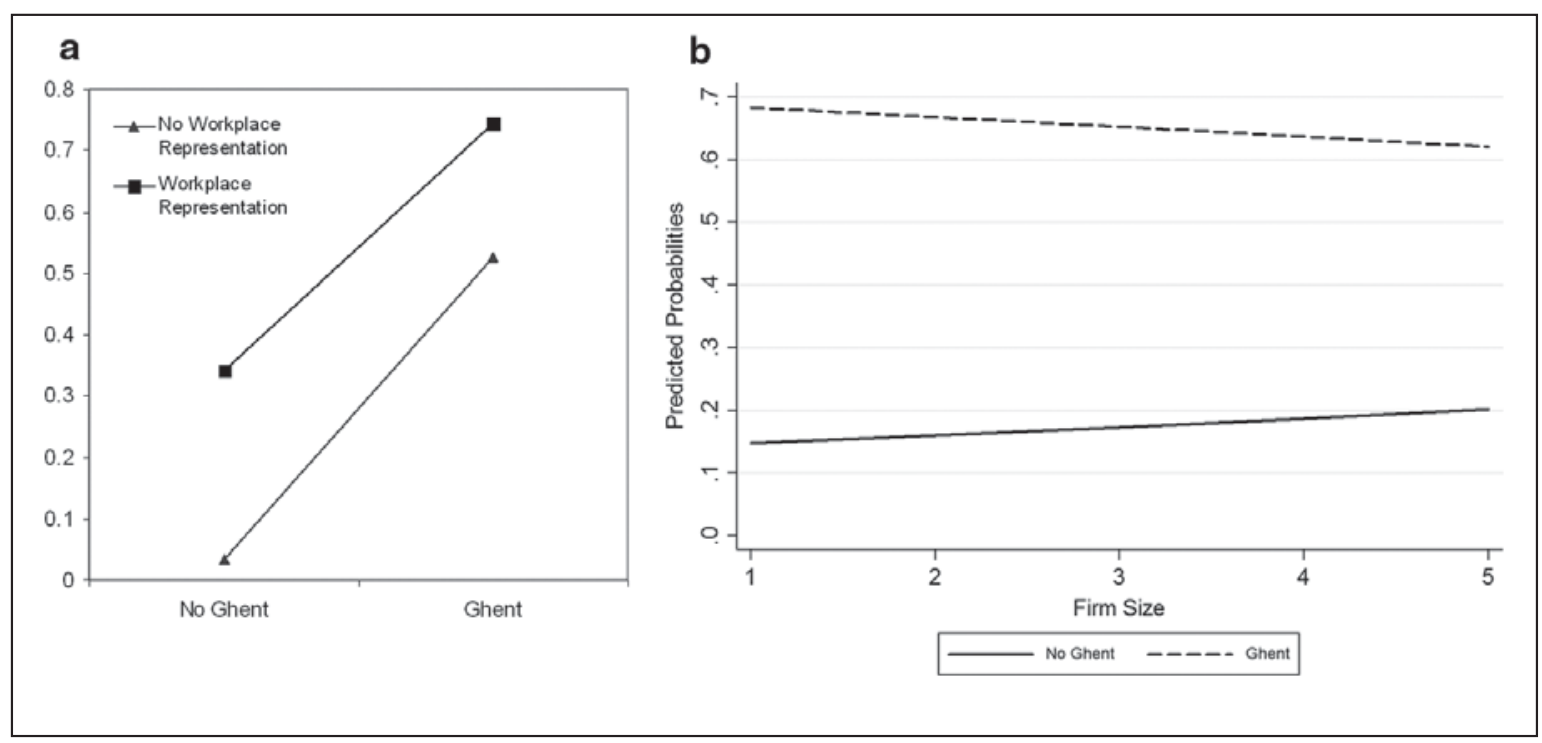

Figure $\mathbf{2 a}$ and $\mathbf{2 b}$. Predicted probabilities of union membership by workplace representation, firm size and Ghent (cross-level-interaction). Source: ESS 2002/03, own calculations. 
the workplace access effect would be already sufficient), while in the other countries, establishment size slightly increases the likelihood of being a union member. Thus, unions in smaller-scale economies without a Ghent system are at a large disadvantage. For instance, Southern economies tend to have more small and medium sized enterprises (SMEs) that make union organizing difficult, while in Denmark despite its SME-based economy the Ghent effect helps organizing employees also in small workplaces. ${ }^{6}$

Finally, we aggregate the variables social capital and workplace representation (see Models 4 and 5) to their country means and introduce them to the model, also deleting their individual level counterparts for these three models to check for the composition effect of these variables. Both macro-variables have a significant effect on union membership when controlling for Ghent. However, when introducing both variables at the same time, workplace representation loses its significant effect (not presented). A bivariate correlation for Ghent and workplace representation reveals a quite strong correlation (.60), thus indicating that a problem of multi-collinearity might exist for these two variables. Including these variables at the macro-level decreases the explanatory power of our models, ${ }^{7}$ though this comes as no surprise when considering that more detailed information is available at the micro-level.

\section{Conclusion}

Our comparative study aimed at contributing to a better understanding of why union membership still differs considerably across European countries today. By multilevel analysis of the ESS, we were able to investigate how individual's decision to unionize is influenced by workplace contextual factors and the society's institutional and social context, while controlling for personal factors. The results of our multilevel analysis strongly support previous studies that point to a positive impact of Ghent unemployment insurance on union membership for gainfully employed (and even more for the unemployed, not studied here). This institutional factor may explain a significant part of cross-national variation, particularly for the top ranked group. However, cross-level interactions show that in Sweden, Denmark, Finland and Belgium, the Ghent effect reduces the positive effect of firm size and workplace representation, while the latter recruitment opportunities are thus of greater importance in non-Ghent countries.

Our study does support the argument that union access to the workplace is a positive context factor in addition to Ghent, explaining why Norway without Ghent is a relatively high density country. As a novel contribution, our study demonstrates that the level of (non-union) social capital in a society has a significant impact on union membership. This could be due to social networks, trust and other-regarding attitudes prevalent in societies with high social capital (Putnam, 2002), but it could also be explained by other macro-variables responsible for the cross-national social capital differences such as values and religion. Future research that compares membership in trade unions with other social, economic and political organizations could reveal specific and more general factors conducive to membership in collective organizations. Future research should also investigate to what degree young employees' lower propensity to join unions will stay a cohort effect and may persist with the next cohorts, or whether it can be decreased over their working life and in future young generations. 
In this study, we could show that institutional, social and workplace contexts matter for an individual's likelihood of union membership. These factors reside beyond the individual: the Ghent unemployment insurance provides perceived selective incentives, and larger firms in general and workplace access for unions in particular help mobilizing members. But also a society's social capital fosters union membership even or particularly in times of de-unionization. This also implies that trade unions have to address an important challenge against the background of declining membership in Europe: how can unions revitalize themselves?

Our results suggest the conclusion that trade unions have to increase their efforts to benefit from the social capital of their members in order to recruit new adherents. Finnish trade unions, for instance, established bonuses for members recruiting new members (Pedersini, 2010). Also, there is a need for coalition-building with other social movement organizations which pursue similar goals. This can also serve a recruitment aim of unions, given our findings that those employees involved in other organizations are more likely to also join a trade union. The German services union ver.di, for example, cooperated recently with Attac and other organizations in order to improve the working conditions of workers at the discount supermarket Lidl. Such strategies that go beyond the organization of workers at already unionized workplaces might help to mobilize atypical workers, who have a lower commitment to their workplace than workers with standard employment contracts. Hence, trade unions need to enhance their activities and thus visibility not only at the workplace but also in society more broadly.

\section{Acknowledgments}

Earlier versions of this article were presented at the EQUALSOC/TRALEG Workshop on the Demise of Collective Organization in Europe (Amsterdam, July 2009) and the EQUALSOC Final Conference (Amsterdam, June 2010).

\section{Notes}

1. More recent rational-choice approaches also include non-economic variables, like attitudes towards unions or ideologies (Schnabel, 2003).

2. Both questions are problematic. The first, which was not repeated in subsequent waves of the ESS, asks about membership of a trade union and other voluntary organizations in the last 12 months, but does not indicate whether a respondent is currently member or not. The second question asks about membership 'of a trade union or similar organization', but what is meant by a 'similar organization' is not specified.

3. The ICTWSS database, collected by Jelle Visser, contains annual data from 1960 to 2007: http://www.uva-aias.net/208.

4. Italy is the main exception as density is twice as high in administratively reported membership statistics (ICTWSS) as in the self-reported ESS data. This is largely because of the exclusion of 'other organizations similar to trade unions' which are relatively widespread in Italy (Ebbinghaus et al., 2008).

5. For the interaction effect of firm size, we included firm size on the individual level as a continuous variable, ranging from 1 to 5 according to the five categories for size. The variable had a highly significant effect $(p<0.001)$ without the interaction and remained highly significant $(p<0.01)$ after including the interaction variable with Ghent.

6. For bivariate cross-national statistics and graphs, see p. 10 in Ebbinghaus et al. (2008). 
7. The log-likelihood decreases from -5646.52 for Model 1 in Table 2, which only includes Ghent on the macro-level to -5697.13 for Model 4 and -6241.59 for Model 5 in Table 2, which include social capital and workplace representation on the macro-, but not on the micro-level.

\section{References}

Akerlof GA (1982) Labor contracts as partial gift exchange. Quarterly Journal of Economics 97(4): 543-569.

Bain G and Elsheikh F (1976) Union Growth and the Business Cycle: An Econometric Analysis. Oxford: Basil Blackwell.

Booth AL and Chatterji M (1993) Reputation, membership and wages in an open shop trade union. Oxford Economic Papers 45: 23-41.

Boudon R (1979) La logique du social. Introduction à l'analyse sociologique. Paris: Hachette.

Bourdieu P (1983) Ökonomisches Kapital, kulturelles Kapital, soziales Kapital. In: Kreckel R (ed.) Soziale Ungleichheiten. Göttingen: Schwartz, 183-198.

Brady D (2007) Institutional, economic, or solidaristic? Assessing explanations for unionization across affluent democracies. Work and Occupations 34: 67-101.

Clegg HA (1976) Trade Unionism under Collective Bargaining. Oxford: Blackwell.

Crouch C (1993) Industrial Relations and European State Traditions. Oxford: Clarendon Press.

Ebbinghaus B (2006) Trade union movements in post-industrial welfare states. Opening up to new social interests? In: Bonoli G and Armingeon K (eds) The Politics of Post-Industrial Welfare States. Adapting Post-war Social Policies to New Social Risks. London and New York: Routledge, 123-143.

Ebbinghaus B and Visser J (1999) When institutions matter: Union growth and decline in Western Europe, 1950-1995. European Sociological Review 15(2): 1-24.

Ebbinghaus B, Göbel C and Koos S (2008) Mitgliedschaft in Gewerkschaften: Inklusions- und Exklusionstendenzen in der Organisation von Arbeitnehmerinteressen in Europa. MZES Working Papers, No. 111, University of Mannheim, available at: http://www.mzes.uni-mannheim. de/publications/wp/wp-111.pdf.

Fitzenberger B and Beck M (2003) Changes in union membership over time: A panel analysis for West Germany. Discussion Paper No. 03-42, ZEW, Mannheim.

Goerke L and Pannenberg M (1998) Social custom, free riders, and trade union membership in Germany and Great Britain. DIW-Diskussionspapier, No. 177, Deutsches Institut für Wirtschaftsforschung, Berlin.

Guest DE and Dewe P (1988) Why do workers belong to a trade union? A social psychological study in the U.K. electronics industry. British Journal of Industrial Relations 26: 178-201.

Hall PA and Soskice D (2001) An introduction to varieties of capitalism. In: Hall PA and Soskice D (eds) Varieties of Capitalism: The Institutional Foundations of Comparative Advantage. Oxford: Oxford University Press, 1-68.

Hancké B (1993) Trade union membership in Europe 1960-90: Rediscovering local unions. British Journal of Industrial Relations 31(4): 593-613.

Hechter M (1987) Principles of Group Solidarity. Berkeley: University of California Press.

Hechter M (2004) From class to culture. American Journal of Sociology 110: 400-445.

Hirsch BT and Addison JT (1986) The Economic Analysis of Unions: New Approaches and Evidence. London: Allen \& Unwin.

Hox J (2002) Multilevel Analysis. Techniques and Applications. Mahwah, NJ: Lawrence Erlbaum Associates. 
Ingham M (1995) Union joining: An empirical test of the social custom model. Applied Economics Letters 2: 245-247.

Kjellberg A (1983) Facklig organisering i tolv länder. Lund: Arkiv förlag.

Korpi W (1983) The Democratic Class Struggle. Boston, MA: Routledge.

Olson M (1965) The Logic of Collective Action: Public Goods and the Theory of Groups, 2nd edn. Cambridge, MA: Harvard University Press.

Pedersini R (2010) Trade union strategies to recruit new groups of workers. Available at: http:// www.eurofound.europa.eu/docs/eiro/tn0901028s/tn0901028s.pdf.

Putnam RD (2000) Bowling Alone. The Collapse and Revival of American Community. New York: Simon \& Schuster.

Putnam RD (ed.) (2002) Democracies in Flux. The Evolution of Social Capital in Contemporary Society. Oxford and New York: Oxford University Press.

Rabe-Hesketh S and Skorndal A (2008) Multilevel and Longitudinal Modeling Using Stata, 2nd edn. College Station, TX: Stata Press.

Rogers J and Streeck W (1995) The study of works councils: Concepts and problems. In: Rogers J and Streeck W (eds) Works Councils: Consultation, Representation, Cooperation in Industrial Relations. Chicago, IL: University of Chicago Press, 3-26.

Rothstein B (1992) Labor-market institutions and working-class strength. In: Steinmo S, Thelen K and Longstreth F (eds) Structuring Politics: Historical Institutionalism in Comparative Analysis. New York: Cambridge University Press, 33-56.

Schnabel C (2003) Determinants of trade union membership. In: Addison JT and Schnabel C (eds) International Handbook of Trade Unions. Cheltenham: Edward Elgar, 12-43.

Schnabel C and Wagner J (2005) Determinants of trade union membership in 18 EU countries: Evidence from micro data, 2002/03. IZA Discussion Paper, No. 1464, IZA, Bonn.

Traxler F (1999) The state in industrial relations: A cross-national analysis of developments and socioeconomic effects. European Journal of Political Research 36: 55-85.

van de Vall M (1970) Labour Organizations: A Macro- and Micro-Sociological Analysis on a Comparative Basis. Cambridge: Cambridge University Press.

Visser J (2002) Why fewer workers join unions in Europe: A social custom explanation of membership trends. British Journal of Industrial Relations 40(3): 403-430.

Visser J (2003) Unions and unionism around the world. In: Addison JT and Schnabel C (eds) International Handbook of Trade Unions. Cheltenham: Edward Elgar, 366-414.

Wallerstein M (1989) Union organization in advanced industrial democracies. American Political Science Review 83(2): 481-501.

Wallerstein M and Western B (2000) Unions in decline? What has changed and why. Annual Review of Political Science 3: 355-377.

Weber M (1922/1972) Wirtschaft und Gesellschaft. Grundriss der Verstehenden Soziologie, 5th edn. Tübingen: J.C.B. Mohr.

Western B (1997) Between Class and Market. Princeton, NJ: Princeton University Press.

Windolf $\mathrm{P}$ and Haas J (1989) Who joins the union? Determinants of trade union membership in West Germany 1976-1984. European Sociological Review 5: 147-165.

\section{Author biographies}

Bernhard Ebbinghaus is Professor of sociology at the University of Mannheim and Director of the Mannheim Centre for European Social Research (MZES).

Claudia Göbel and Sebastian Koos are lecturers in sociology at the University of Mannheim. 